\title{
Staff Development Needs In Pakistan Higher Education
}

\author{
Muhammad Hameed Ullah, Riphah University, Pakistan \\ Muhammad Naeem Ullah Khan, Muslim High School, Pakistan \\ Ali Murtaza, Preston University, Pakistan \\ Muhammad Naseer Ud Din, IER, Kohat University, Pakistan
}

\begin{abstract}
Staff development is very significant for the achievement of overall goals of higher education in Pakistan. The success of innovations depends largely upon the skills of instructors; but in Pakistan, the people with a simple masters degree (without any pedagogical training) are inducted as teaching staff at the university level, so it is time to explore whether or not the inducted teachers feel the need for training. Further to be explored are areas in which they are interested in being trained. Therefore, the objectives of study were 1) to explore the training needs for university teaching staff, 2) to identify the areas in which development is needed by the teaching staff of the universities in Pakistan, and 3) formulation of recommendations for staff development in Pakistan to improve education at the higher level. The sample comprised of $20 \%$ randomly-selected teaching staff of ten selected universities, degree-awarding institutions from the public sector, and $40 \%$ teaching staff of ten selected universities from the private sector. A selfdeveloped questionnaire, consisting of 41 items to be responded to on a five-point Likert scale and two open-ended questions, was used to collect data. The principal researcher approached all the respondents personally by repeated visits and got the completed questionnaires, so this questionnaire also served the purpose of an interview. The analysis of data revealed that the university teachers need training in the following areas: philosophy of education, Islamic philosophy of education, educational psychology, research techniques, professional trends, professional competencies, professional attitude, professional ethics, global innovations in teaching strategies, classroom management, counselling and guidance, student discipline, communication skills, learning theories, and supervision. Therefore, it is recommended that they may be included in the training curriculum of university teachers.
\end{abstract}

Keywords: Staff Development; Higher Education; Philosophy of Education; universities

\section{INTRODUCTION}

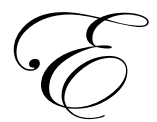

ducation is a process to give intellectual, moral, and social instruction, especially as a formal prolonged process that includes training or instruction for a particular purpose (Anjum, 1998). Teachers represent the ideals and aspirations of the nation and owe to it the moral and mental accountability of equipping the youth for active participation in the high enterprise of creating a social order, which shall dispense equal justice to all and sundry (Kakkar, 1996) . Higher education enhances social, cultural and economic development, active citizenship, and ethical values. Institutions of higher education have the main responsibility for equipping individuals with advanced knowledge and skills required for positions of responsibility in government, business, and the professions (Isani and Virk, 2004). The training of high-level scientific manpower is a matter of vital national concern in every country. The development of higher education is thus connected to economic development (Sheikh, 1998). A country's social and economic development depends on the nature and level of higher education. The claim of McGill (1992) that "in the developed countries, the role of higher education in production of high quality human capital is quite evident" is valid and reliable. The role of the university in a developing country must be to educate its people and produce scholars who, in return, should be able to contribute to the overall human development (Wickrama, 1996). 
The success of reforms in an educational institution depends upon the quality of teacher, which, in turn, depends to a great extent on the quality of teacher education. Staff development aims at building and promoting an effective personality through learning and trait strengthening programmes. It includes development of skill-oriented vision, mental poise, unbiased perception, vigilance, drive, communication skills, team building, competence in decision-making and problem-solving capabilities, honesty, etc, and the art of encouraging, as well as tolerating different viewpoints, including dissent in the staff (Sisodia, 2000).

The quality of higher education depends upon the quality of staff in higher educational institutions. The role of staff is pivotal for the achievement of goals of an institution or an organization. A high quality and wellmotivated teaching staff is essential in building excellence in education. Staff development is the sum of activities that enhance the knowledge, skills, performance, vision and understanding of the staff. In educational institutions, a staff development programme improves the communication skills, classroom behaviour, teaching methods and thinking of the teacher. The purpose of staff development is to promote the quality of pupils' learning by different teaching strategies.

The main objectives of this study were:

1. To explore the training needs for university teaching staff

2. To identify the areas in which development is needed by the teaching staff of the universities in Pakistan

3. Formulation of recommendations for staff development in Pakistan to improve education at the higher level

\section{METHODS AND PROCEDURE}

The study was focused on "training needs assessment for university teachers". The study was a descriptive/survey type. The following procedure was adopted for the study.

\section{Population}

University teachers, who were readily involved in the teaching process in public and private universities, were the population of the study.

\section{Sample}

The sample consisted of 830 university teachers. There are more than 100 universities in the public and private sector in Pakistan. It was very difficult for the researcher to visit each university; hence, 20 universities were randomly selected and included in the sample, ten from the public sector and ten from the private sector. Twenty percent of the teaching staff of public universities and $40 \%$ of the staff at private universities was selected for study

\section{Research Instrument}

A self-developed questionnaire, consisting of 41 items to be responded to on a five-point Likert scale and two open-ended questions, was used to collect data.

\section{Data Collection}

The data collection stage was very difficult for the researcher. He had to visit most of the sample universities again and again. The researcher distributed the questionnaire to 830 respondents, but was able to get responses from only 800 respondents. 


\section{RESULTS}

Table 1: Need of Training (Percentage Frequencies to the Nearest Whole Number)

\begin{tabular}{|c|c|c|c|c|c|}
\hline Statement & $\begin{array}{l}\text { Strongly } \\
\text { Agree }\end{array}$ & Agree & Neutral & Disagree & $\begin{array}{l}\text { Strongly } \\
\text { Disagree }\end{array}$ \\
\hline $\begin{array}{l}\text { Professional training is essential for staff of Higher Education } \\
\text { Institutions (universities) }\end{array}$ & 81 & 14 & 1 & 1 & 3 \\
\hline Pre-job training is necessary after selection. & 38 & 35 & 15 & 11 & 1 \\
\hline $\begin{array}{l}\text { Need assessment is necessary before launching the training } \\
\text { programme. }\end{array}$ & 59 & 34 & 6 & 0 & 1 \\
\hline
\end{tabular}

Table 1 shows the trend of respondents toward 'strongly agree' which indicates that training is essential for university teachers and they also need pre-job training after need assessment. The results of the table support Noureen (2003) who found that staff development programmes are necessary for teachers. The results also support Sultana (2004) who found that training is necessary for teachers while they are on the job.

Table 2: Identified Fields of Training (Percentage Frequencies to the Nearest Whole Number)

\begin{tabular}{|l|c|c|c|c|c|}
\hline \multicolumn{1}{|c}{$\begin{array}{c}\text { Academic staff of Higher Education Institutions need } \\
\text { training in the fields of }\end{array}$} & $\begin{array}{c}\text { Strongly } \\
\text { Agree }\end{array}$ & Agree & Neutral & Disagree & $\begin{array}{c}\text { Strongly } \\
\text { Disagree }\end{array}$ \\
\hline Philosophy of Education. & 44 & 47 & 6 & 3 & 0 \\
\hline Islamic Philosophy of Education & 49 & 41 & 7 & 2 & 1 \\
\hline Educational psychology & 47 & 45 & 7 & 1 & 0 \\
\hline Research techniques & 63 & 35 & 2 & 0 & 0 \\
\hline Professional trends & 43 & 47 & 9 & 1 & 0 \\
\hline Professional competencies & 55 & 38 & 7 & 0 & 0 \\
\hline Professional attitude & 47 & 40 & 9 & 4 & 0 \\
\hline Professional Ethics & 34 & 54 & 11 & 1 & 0 \\
\hline Global innovations in teaching strategies & 62 & 32 & 6 & 0 & 0 \\
\hline Classroom Management & 33 & 44 & 12 & 6 & 5 \\
\hline Counselling and Guidance & 37 & 44 & 11 & 5 & 3 \\
\hline Student discipline & 40 & 54 & 4 & 2 & 0 \\
\hline Communication skills & 57 & 38 & 5 & 0 & 0 \\
\hline Learning Theories & 38 & 43 & 11 & 6 & 2 \\
\hline Supervision & 35 & 48 & 15 & 2 & 0 \\
\hline
\end{tabular}

Table 2 shows that the trend of respondents is toward 'strongly agree' which indicates that training of the university staff is desired in the field of philosophy of education, Islamic philosophy of education, educational psychology, research techniques, professional trends, professional competencies, professional attitude, professional ethics, global innovations in teaching strategies, classroom management, counselling and guidance, student discipline, communication skills, learning theories, and supervision.

Table 3: Training in Instructional Development (Percentage Frequencies to the Nearest Whole Number)

\begin{tabular}{|l|c|c|c|c|c|}
\hline \multicolumn{1}{|c|}{ Statement } & $\begin{array}{c}\text { Strongly } \\
\text { Agree }\end{array}$ & Agree & Neutral & Disagree & $\begin{array}{c}\text { Strongly } \\
\text { Disagree }\end{array}$ \\
\hline Preparation of Instructional Material & 36 & 48 & 14 & 2 & 0 \\
\hline Preparation of Lesson Plan & 38 & 43 & 11 & 6 & 2 \\
\hline Use of A.V. Aids & 37 & 53 & 9 & 1 & 0 \\
\hline Time Table planning & 39 & 50 & 7.5 & 2.5 & 1 \\
\hline
\end{tabular}


Table 3 shows that the trend of respondents is toward 'strongly agree' which indicates that the teachers are anxious to get training in preparation of instructional material, lesson planning, use of A.V. aids, and time table development.

Table 4: Training in Test Construction (Percentage Frequencies to the Nearest Whole Number)

\begin{tabular}{|l|c|c|c|c|c|}
\hline Statement & $\begin{array}{c}\text { Strongly } \\
\text { Agree }\end{array}$ & Agree & Neutral & $\begin{array}{c}\text { Disagree } \\
\text { Strongly } \\
\text { Disagree }\end{array}$ \\
\hline Preparation of question papers & 32 & 60 & 6 & 2 & 0 \\
\hline Marking of tests & 32 & 54 & 10 & 4 & 0 \\
\hline Interpretation of results & 44 & 44 & 9 & 3 & 0 \\
\hline Feedback based on evaluation & 44 & 45 & 8 & 3 & 0 \\
\hline Use of Library & 53 & 40 & 5 & 2 & 0 \\
\hline
\end{tabular}

Table 4 shows that the trend of respondents is toward 'strongly agree' which indicates that the teachers want to get training in test formation, preparation of question papers, marking of tests, interpretation of results, and feedback based on evaluation. Training is also desired in the use of library.

Table 5: Training in Computer Usage (Percentage Frequencies to the Nearest Whole Number)

\begin{tabular}{|l|c|c|c|c|c|}
\hline \multicolumn{1}{|c|}{ Statement } & $\begin{array}{c}\text { Strongly } \\
\text { Agree }\end{array}$ & Agree & Neutral & Disagree & $\begin{array}{c}\text { Strongly } \\
\text { Disagree }\end{array}$ \\
\hline Software & 44 & 41 & 6 & 9 & 0 \\
\hline Internet usage & 55 & 35 & 7 & 3 & 0 \\
\hline
\end{tabular}

Table 5 shows that the trend of respondents is toward 'strongly agree' which indicates that the teachers are anxious to learn about the computer, its hardware, software, and how to use the internet.

Table 6: Financial Matters (Percentage Frequencies to the Nearest Whole Number)

\begin{tabular}{|l|c|c|c|c|c|}
\hline \multicolumn{1}{|c|}{ Statement } & $\begin{array}{c}\text { Strongly } \\
\text { Agree }\end{array}$ & Agree & Neutral & Disagree & $\begin{array}{c}\text { Strongly } \\
\text { Disagree }\end{array}$ \\
\hline Training is needed in Generating funds & 22 & 45 & 20 & 10 & 3 \\
\hline Training is needed in Budget preparation & 33 & 44 & 14 & 8 & 1 \\
\hline Training is needed in Budget utilization & 41 & 40 & 12 & 5 & 2 \\
\hline Training is needed in Audit of funds & 37 & 39 & 15 & 8 & 1 \\
\hline
\end{tabular}

Table 6 shows that the trend of respondents is toward 'strongly agree' which indicates that the teachers are anxious to learn about how the funds are generated, how the budget is prepared, what is the proper way to utilize the budget, and what are audit requirements.

\section{CONCLUSION}

The majority of the respondents admitted that professional training is essential for staff of higher education institutions. Training typically provides employees with the knowledge and skills needed to do a particular task and also to change their attitude in favour of their performance. The academic staff of higher education institutions need training in the fields of philosophy of education, Islamic philosophy of education, educational psychology, research techniques, professional trends, professional competencies, professional attitude, professional ethics , global innovations in teaching strategies, classroom management, counselling and guidance, student discipline, communication skills, learning theories, and supervision.

From the study, it is concluded that teachers are anxious to get training in preparation of instructional material, lesson planning, use of A.V. aids and time table development, test formation, preparation of question 
papers, marking of tests, interpretation of results, and feedback based on evaluation. Training is also desired in the use of the library, computers, how funds are generated, how the budget is prepared, what the proper ways of utilization of the budget are, and what audit requirements are.

\section{RECOMMENDATIONS}

1. Staff development is primarily concerned with the identification, formation and enhancement of skills. Professional training is essential for staff of higher education institutions. Training typically provides to employees the knowledge and skills needed to do a particular task and change their attitude in favour of their performance. Therefore, it is recommended that a training program must be declared compulsory for the teaching staff of higher education institutions.

2. It has been proven in the study that the teachers of higher education were deficient in the fields of philosophy of education, Islamic philosophy of education, educational psychology, research techniques, professional trends, professional competencies, professional attitude, professional ethics, global innovations in teaching strategies, classroom management, counselling and guidance, student discipline, communication skills, learning theories, and supervision. Therefore, it is recommended that they may be included in the training curriculum of university teachers.

3. Institutions play a vital role in grooming the individuals, and practical things are very essential for the performance of daily institutional work The study showed that preparation of instructional material, lesson planning, use of A.V. aids, and timetable development are the desired areas in which university staff want to become experts. Therefore, it is recommended that proper training arrangements should be arranged for the staff in this regard.

4. Test formation, preparation of question papers, marking of tests, interpretation of results, and feedback based on evaluation are the areas which are not given importance at the university level. However, it is very important to make the university teaching staff experts in these areas. Training workshops should be arranged in this regard. Training is also desired in the use of library.

5. Without computer knowledge, one cannot survive in the field of higher education; but in higher education, the teaching staff don't even know the basics of a computer. Therefore, it is recommended that for the entire teaching staff, there should be compulsory training in M.S word, Excel, Power Point and internet usage to make the staff compatible with the modern world.

6. Funds are like blood to run the institutions. In public institutions, it is very important to know how the funds are generated, the legal use of the funds, the rules and regulation for use of the funds, how the budget is formed for the departments and institutions, and how they are utilized. These are the areas that demand training, so it is recommended that comprehensive training should be arranged to familiarize higher education teaching staff on financial matters.

\section{AUTHOR INFORMATION}

Dr. Muhammad Hameed Ullah is working as an Assistant Professor, Riphah International University, Islamabad, Pakistan.. He did his Ph.D. in Education from University Institute of Education and Research, UAAR, Pakistan.

Dr. Muhammad Naeem Ullah Khan is working as Principal Jinnah Memorial Muslim High School, Gujranwala, Pakistan. He did his Ph.D. in Education from University Institute of Education and Research, UAAR, Pakistan.

Dr. Ali Murtaza is working as an Assistant Professor Preston University Islamabad, Pakistan. He did his Ph.D. in Education from University Institute of Education and Research, UAAR, Pakistan.

Dr. Muhammad Naseer-Ud-Din is working as an Assistant Professor in Institute of Education and Research, Kohat University of Science and Technology, Kohat, Pakistan. He did his Ph.D. in Education from University Institute of Education and Research, UAAR, Pakistan. 


\section{REFERENCES}

1. Anjum, G. H.( 1998). Education \& the Challengers of $21^{\text {st }}$ Century. Pakistan Education Forum, Lahore. p. 38.

2. Isani, C. U. AG and M. L. Virk. (2004). Higher Education in Pakistan: A Historical and Futuristic Perspective. National Book Foundation, Islamabad, Pakistan. pp.4-8.

3. Kakkar, S. B. (1996). Changing Perspectives in Education. Viskas Publishing house Pvt. Ltd. New Delhi, India. pp. 78-94.

4. McGill, S. B. (1992). Changing Role of Institutions and Colleges. In. the Journal of Higher Education. Vol.11 No.2, New Jersey. P.47.

5. Noureen, G. (2003). A Study of Relationship Between School Heads Management Competencies with School Effectiveness and Designing of an In-service Training Programme for Institution Heads in Pakistan. (Unpublished Ph.D. thesis), University of the Punjab, Lahore. pp. 1-225.

6. Sheikh, N. (1998). Higher Education in Pakistan. In: Talat J. et al. (eds.): Higher Education: A pathway to Development, Agha Khan University Press, Karachi. P. 30.

7. Sisodia, M. L. (2000). Higher Education Growth and Future Options. University Book House Pvt. Ltd. Jaipur, India. P. 111, 117.

8. Sultana, N. (2004). Need Assessment and Designing A Model for Professional Development of College Teachers in Pakistan. (Unpublished Ph.D. thesis). University of Arid Agriculture, Rawalpindi, Pakistan. pp.1-257.

9. Wickrama, B. A. (1996). Higher Education in Ceylon. In: UNESCO Bulletin, Vol. VIII No.1, UNESCO Asian Regional Office, Bangkok. P.34. 